\title{
Legal Effect of Subtract Physical in Iranian Jurisprudence and Law
}

\author{
Ali Khalafi ${ }^{1}$, Mohammad Roshan ${ }^{2}$, Ebrahim Taghizadeh $^{3} \&$ Abbas Karimi $^{4}$ \\ ${ }^{1} \mathrm{PhD}$ in Private Law, Payam Noor University, Iran \\ ${ }^{2}$ Faculty Member and Associate Professor of Shahid Beheshti University, Iran \\ ${ }^{3}$ Faculty Member and Associate Professor of Payam Noor University, Iran \\ ${ }^{4}$ Faculty Member and Associate Professor of Tehran University, Iran \\ Correspondence: Ali Khalafi, PhD in Private Law, Payam Noor University, Iran. E-mail: Mamhs14@yahoo.com
}

Received: March 8, 2017

doi:10.5539/jpl.v10n3p104
Accepted: March 24, 2017 Online Published: June 1, 2017

URL: https://doi.org/10.5539/jpl.v10n3p104

\begin{abstract}
In Iranian law, only entities that can be said is similar to physical subtraction, iddah entity after revocable divorce. During the iddah, couples living together have some obligations, but not forced to lay in between. And in another, though, for fear the loss of his wife, is allowed to subtract the location of the shared residence. It must be said that this system is rational and human relations based on the wisdom of civilization is permissible insofar as it does not conflict with Islamic law. If intellectuals of today's society conclude that stipulated in the divorce decree was not rational and not in the interest of society must predict good strategies to restore them to life and as far as possible be required. Basically, physical subtraction is expected to act before divorce to assess at this time to prevent the occurrence of problems after divorce and couples come to life with stability.
\end{abstract}

Keywords: compliance, physical subtraction, court verdict, emotional divorce, iddah

\section{Introduction}

According to the legal system's approach can be stated that discussions' physical subtraction is not accepted in Iranian law and has no place in Iran and any petition under this title is not yet completed, but the physical subtraction, emerging method which in recent years, gradually and differences among couples that are having a difficult time spread that during this period, and the continued custody of the couple's good for the children is required to expend wife and children, the couple's commitment to a shared life has continued and the only sexual relationship cannot be regarded as rights and duties of the couples. Because the couple for various reasons, although they live together, but no attention and interest in each other and not being together and only due to the presence of children or to reach the final point of separation while their heads together and prefer to stay away from each other. It can be said that although Iran's rights, physical subtraction is not detected, but according to its bases in the Holy Quran, the Traditions issued by the infallible Imams (AS) and social interests can be predicted in the law as the appropriate solution for further reflection and understanding of reality couples divorce and separation is to provide good conditions with proper management and families do not consider divorce as the last method to get rid of abnormal divisions circle of family and social conditions, economic conditions and cultural life and to think in order to prevent the disintegration of the family and improve their lives and better their children.

\section{First Topic: Position of Protecting the Non-Financial Rights in the Principles Governing the Family}

\subsection{First Speech: Concept and Nature of Custody}

The Civil Code does not define the word, but some Shiite jurists have argued that the definition of "custody of the province and the reign of the train and its accessories such as the maintenance of the child, she lay in bed, pulling blue, and clean up, wash his clothes like that" (Ashtiani, 1992; Juba'i al'Amili et al. 1992). So most observers to support physical custody of the child, although the child's moral and psychological support in the legal entity, both in Islamic law have said: a person who is granted custody of the child should be released to him, Muslims, (if the child is a Muslim) faithful. Also, some Shiite scholars have said that a mother who is charged with custody cannot take the child out of the city to the village, because better education is provided for children in the village (Tusi, 1980; Najafi, 1987). Furthermore, the definition of the word education that scholars have used child has the dual physical and mental, physical and spiritual, and does not have to develop physically. 
Article 1173 of the Civil Code also refers to the spiritual and moral aspects of custody, what this article provides that if the non-caring parent child's physical or moral degeneration of the moral education of the child is in danger, the court may adopt any decision necessary to know about child custody. Once in the custody rights or the right and duty of Shiite scholars disagree. Two comments on this issue have been proposed: (Mughniyeh, 1964; Najafi, 1987). Some scholars believe that custody is an individual right and hence pure and simple can be dismantled and transported. Another batch of Shiite scholars believes that custody is the right and duty orifice; the holder of custody cannot waive it, or move, or change in the divorce, and custody of the mother who is responsible, because your duty does not charge fees in return. The second recommendation is accepted civil law because Article 11168 provides: "Maintenance of children is both the right and duty of parents." And Article 1172 says: "None of the parents are not allowed, while it is assumed custody of the child, refuse to hold him/her. If one of the parents refuses to govern the requirements to request another or the guardian or someone close or to demand of the public prosecutor ${ }^{1}$ to each of the parents that the child is held responsible for his/her custody and if that requirement is impossible or ineffective, spends custody if the parents are deceased father and mother meet expenses. The solution that has been accepted in civil law with the best interests of the child is always the legislator Islam and Iran is more compatible. There is no doubt that the child needs care and affection from parents and especially mothers and why it is enough to custody to someone who is ready to study it.

\subsection{Second Speech: Good Companionship}

Exploring the law, we realize that determine the type of assignments related to the couple has not gone unnoticed in the eyes of legislators and this in the Civil Code (articles 1119-1102) states that at length to each of the spouses in case of violation of their duty under the law to be dealt with. Among them are the good companionship. What about the moral aspect of good companionship, (Roshan, 2014) but courting each spouse abuse in civil law consequences which the law is to newsgroups, including Article 1103 of the Civil Code, which required the couple to good companionship and Article 1108 says that affect women socializing, being deprived him of alimony and Abuse Act of 1111 that relate to socialize man. If the man refuses to give alimony and other issues, has taken the necessary measures. So the legislation on family practices as a base for the growth of human emotions and satisfying natural needs and the evolution of mental development that is affected is quite distinct from that of the other legal systems in the form of administrative regulations to be realized and justified. According to Article 1103- couple Hasan obliged to socialize with each other. The first task in the relationship between husband and wife, good companionship that plays a crucial role in the relationship between couples and family stability. A couple of two families are different and may be disagreement arise between them; in this case, both sides must be consistent and compassionate. Within the meaning of good companionship wrote: "The good companionship association against abuse, meaning good deeds... established mutual rights of couples in love and mercy and good child upbringing and family life, a particular kind of behavior towards each other loving couples that term is said to be good companionship. In general, good companionship Quranic concept is that the verse of Surah Nisa; i.e. spouses Socialize with good morals and to treat them kindly." ${ }^{2}$ This good manners and understanding ${ }^{3}$ based on the famous and worthy behavior and socialize, form the basis of married life and this is the same principle expressed in many verses of the Holy Quran and it emphasizes. Realization of the principle of love and mercy and preserve peace and settlement, and facilitate optimal growth and improve each family member, Raheen compliance with the major task of the spouse; therefore, any action that induces anxiety, stress and woes, grief, hatred in the home and family, reprehensible and despicable (Mir Khani, 2000). The scope and for good companionship more authors, reviewers considered customary criteria. Doctor Katouzian in this regard, writes: "Writing good companionship cannot be determined in detail because the degree of civilization and moral habits and social customs and religion among the people, creates a certain concept of good companionship, but in short we can say all things that offend public opinion or things that are incompatible with the love of family and the requirements of love between the two spouses, the associate instances of abuse in the family" (Katouzian, 2010). Good companionship couple or good behavior related to practices and social customs and habits will change its requirements in terms of time and location. In general, it can be said that the couple requires good companionship and intimacy cheerfully and peacefully live together and avoid bickering and insults and insulting each other. In the case of joint residence for good companionship addition, having sex is considered good companionship conventional appliances (Safai and Emami, 2013). Some also enumerated as examples of good people (in the sense of tolerance and openness, as well as the right and left not abandon falsehood), honor,

\footnotetext{
${ }^{1}$ Under Article 12 of the Law of Public and Revolutionary Courts Act of 1994 Chief Justice of the city in non-litigious matters, was the deputy prosecutor.

${ }^{2}$ Introduction to family law in the Civil Code, available at www.taanir.com/articles

${ }^{3}$ Psychologists have an understanding and ability to withstand significant difference.
} 
and respect each other, love and expressing it, covering defects wife $^{4}$, forgiveness, the tolerance, consultation and exchange of ideas for good companionship (Ibid). It is to this origin principle and the principle of "love and mercy" and "Settlement of disputes and consent" and other such principles, the principles are the ruling. The code of conduct requires proper understanding of the Qur'an is actually a moral system is in place to reflect on a few points:

1) Man of the matter, "Anise" consistency of social life is based on relationships with others and ways of humankind, as to realize their development needs to communicate with others. How is the quality of this interaction? Socialize and which is famous? It is necessary to explain the entry "A" justification "B".

2) Associate of the social implications of this verse is therefore a crucial two-way interaction between husband and wife and men and women from this angle that both should be treated as equal as equal.

As Tafsir al-Manar, on said: "The concept of association, participation and equality lies; This means that men and women behave according to conventional and well-known women should socialize with men on base"(Rashid Reza). Famous words frequently in the Qur'an and 19 dealt with the issue of courting men and women in the family, is a broader and deeper sense of legitimacy and justice-oriented and as such is a legal right and fair, work values, ethical and human are also the means to conduct a charity and worthy addition to the high values of justice and human. In other words the duty of obligatory step beyond and the action is desirable. The famous definition of Allameh Tabatabai says: "Famous is what ensures the guidance of reason, religious order and virtue, the virtue of good character, good traditions and practices (Tabatabai, 1984). Late Tabarsi writes: "coexistence accordance with the decree of God's purpose is to fulfill women's rights, such as the right to sexual enjoyment, alimony payments and beautiful words; it is known that physical abuse and verbal confrontation with his wife in vogue and is not valid... "(Al-Tarihi). It considered in addition, truth, justice, good behavior and speech, openness and respect and ethical values in the area of the "famous" is included. It is also important to note that the term "known" and signs it in a way and style that brings the general law and is incompatible with any allocation and restriction. Now the question arises what is the criterion of good companionship? What comes from the words of religious figures, is the criterion of good companionship, customs, traditions and dignity of women. The purpose of the customs, traditions and values that have not strayed from the path of nature and common sense and happiness, not contradict the goals and motivations of a family. Finally, any behavior that takes place in the famous area, necessary and any behavior that falls outside of this circle would be considered desecration and lack of respect, bad. What a beautiful Quran says that it is necessary to observe the system treating a husband on the basis of mutual respect and concern for the dignity of human beings to be the spouse.

\subsection{Third Speech: Couples Assistance for the Welfare of the Family and the Upbringing of Children}

According to Article 1104- couples need assistance to each other for the welfare of the family and the education of their children. The matter is that the couple should be in all matters relating to marriage, with the cooperation and collaboration. Meaning the welfare of their family, men and women trying to close the manner and method and mood of men and women to each other; so that the cordial relationship and understanding it are two different dimensions, thus becoming one and the unity and strength of marriage is to be achieved. One could also say family foundations and it is the love of husband and wife to each other is the guardian of chastity and purity survival of the family and makes the piety of each man and woman (Mir Khani, 2000). The couple have two cultures and two different persons, so the disagreements between the two seems natural. Comments couple occurs when the balance between these two forgiving and tolerant towards each other when necessary for family life, differences aside and respect the opinions and sympathy to their family affairs. Peace in the common life is emerging that is based on the foundations of relations between husband and wife emotional, rational and moral. For this reason, the legislator first and most important tasks put a couple of good companionship and cooperation. The scope of the assistance and cooperation in customs and legal circumstances of the time and location criteria is known (Katouzian, 2010; Safai and Emami, 2013).

\section{Second Topic: The Financial Support of the Principles of Family}

\subsection{First Speech: Common Property}

In Iranian law, the definition of the fiscal regime is not given; but the couple's financial independence is defined in Iranian law as husband and wife after marriage (during the marriage) are two distinct and separate assets. Women and men do not constitute a common property assets and wife after marriage in the office, and the

\footnotetext{
${ }^{4}$ Article 1114 provides that: women should be settled in the house that determines the husband unless he is given the authority to determine home to the woman.
} 
seizure of property and assets of the former set or property acquired during the marriage completely independent and can be any material and legal action against them. President of the husband over the family, any optional on the property of the wife, for he does not exist and after the dissolution of the marriage, there will be no common property, as it is in Western countries and other customary rights.

\subsection{Second Speech: Alimony}

\subsubsection{The Concept of Charity}

Our Civil Code does not provide a definition of alimony. Only in his 1107 article, instances, it is stated: "Alimony is defined as housing, clothing, food and furniture that traditionally are related to the situation of women, and a servant woman used in case of illness or impairment Member or his need." But legal doctrine, said: "All of the things that a woman alimony, according to the degree of civilization and living environment and their physical and mental conditions, which require (Katouzian, 2010).

\subsubsection{Principles of Alimony from the Perspective of Shia Scholars}

What about the causes and the husband to pay a child support obligation? From the perspective of Shia scholars have raised three grounds.

\subsubsection{Subservient Wife}

Instead, compliance or Shiite jurisprudents as well as the maintenance was changed overnight and it was conditional on obedience. Alimony obligation conditional on permanent contracts and full compliance knew. Sahib Riyadh (Tabatabai, 1983) also knows as alimony instead of transactions against compliance. The reason given is ultimately subservient to tradition, reputation among jurists and no verse and narrative implies that they have this condition, Kashf al-litham (Hindi, 1984). After all the evidence denies deference to tradition, holds fast to the principle of Innocence husband to pay maintenance (in case of non-compliance). While there is no presumption of innocence in a place that runs reason of the Book and the Sunnah; another drawback that if the alimony obligation, subject to compliance must be provided in case of denial of the necessity of the rule is conditional, meaning that if compliance is not possible for reasons such as promotion or any other blemish, alimony obligation is ruled out (Najafi, 1987) would otherwise have to excluding these special reasons to be filed.

\subsubsection{Contract and Precision Disobedience}

A group of jurists (Momen Sabzevari, 1987). Only marriage will cause alimony and, in proof of this theory said: Alimony obligation because the evidence, it was shipped and the parity is achieved as the wife upon marriage, after the marriage, the obligatory charity, and disobedience can only downfall is alimony. Mohades Bahrani says: for necessity of compliance-based maintenance, there is no reason for explicit and implicit, but mere claims and arguments and news, alimony obligation based on a single contract is known (Bahrani, 1987).

\subsubsection{President of Husband Right}

Another appears to be based on more accurate in issue, is that the right to alimony or custody of the husband over the head of the family (wife) we know that the jurisprudence of the "right of obedience" has been interpreted. It seems verses and hadiths also reflects this theory (The Holy Quran, Nisa / 34). The men are headed by women, because Allah has made some of the advantages that put others and because they spend out of their property that (in the case of women). God in the above verse is a task put in front of the right one. The head of the family and careers and affairs of the family of the rights due to the characteristics of physical, mental and spiritual natural man entrusted to him and the man obliged to provide spending his/her life. After the verse above tells the husband of Administration and the Department of wisdom or because of the privilege and right of him and says: "This led to differences that God is a creator of human beings expediently placed between them" and immediately in front of such a right, duty and responsibility of the husband and say: "This sponsorship for the charity commitments and payments that men are responsible for women and family" (Makarem Shirazi, 1995). This implies that the obligation to pay alimony is headed by men. As Saheb Javaher stated such interpretation of the verse does not breathe (Najafi, 1987).

And some Arabic-speaking lawyers as well, with such an interpretation of the above verse, husband headed to the right spend with the woman in Islamic law, was mentioned (Zuhayli, 1999). Investigating the traditions including the right of couples and the right of the wife to the husband than the wife's. As Saheb Javaher stated (Najafi, 1987) to support the base is known; such a theory is expressed. For the category of narratives to express to the couple's wife and another set of narratives that express the wife over the husband's right, it is inferred. Hence Saheb Javaher after the rejection of tradition compliance, "the right obedience" as a condition for 
accepting the necessity of alimony and says: quote justified, stipulating the "right obedience" in the problem and lack of obedience is disobedience which, will in alimony fall. Elsewhere in the same book says: "Finally, something that used the traditions of obedience and rights of couples, is that in the absence of obedience, by her disobedience and the right pair can be obtained in the discharge of his fault; wife's alimony will fall" (Ibid).

\subsection{Third Speech: Legal Basis of Alimony}

Civil Code in Article 1106, Alimony and funding for the husband's family has taken. ${ }^{5}$ But what is the basis or cause such a duty with which of the three grounds raised in accordance Shiite jurisprudence, there is no explicit provision. For this reason, some authors were not alimony civil rights issue in this debate. But some law professors of civil rights laws implicitly on the second - marriage and precision disobedience - and so they were deduced: "Civil Code in this regard no explicit provision in the law is not unanimity, but the tone of deference to the legislature in 1102 to be eligible after that comes the woman does not know, but disobedience to prevent it counts, because under this article was the fact that marriage is correct, conjugal relationship existing between the parties and the rights and duties of the couples against each other to be positioned. One of these assignments, requiring the man to pay the expenses, except in accordance with Article 1108, disobedience woman eliminates this requirement" (Katouzian, 2010). This can be said because civil law is silent on this issue or at least ambiguous and brief; thus, when a dispute, the judge is obliged under Article 167 of the constitution to sources and authentic fatwa accept that necessity has provided support to the necessity of obedience. Perhaps the difference principles mentioned at the outset, not seem so important, but it should be noted that in addition to the theoretical aspects, will result in significant effects from the practical to the burden of proof in that case who is responsible.

\subsection{Fourth Speech: The Right of Women in Dowry}

That in terms of habits and customs dowry to their husband's home, is not considered as a waiver of ownership and is wholly owned by women and men have no right to manipulate or convert furnishings. Only man can do at conventions and common tools, because under article 1118 of the Civil Code, the financial independence of women is recognized and the property of the woman's dowry and marry their dowry that behave any way she likes. So in terms of women's rights is not mandatory in the preparation and taking of dowry to her husband's house and husband after marriage dowry is not the owner but traditionally can use these devices and take advantage of its benefits. Dowry does not mean the withdrawal of women from ownership or sharing of man, but man cannot use the benefits by allowing women, according to dowry law a "permissible capture" and does not create any right for a husband because she can transfer to another dowry. Woman's dowry is not in possession of a dedicated man and the couple have in common both to capture this property so we can say that her husband was with the officer not to hold the dowry. The opinions of the Supreme Court, the receipt dowry of man alone is not enough to claim her dowry must prove that the man is at home. Receipts dowry and dowry same effect as the survival of man can claim for it. ${ }^{6}$

\subsection{Fifth Speech: Inheritance}

Inheritance in the word means something remains rest (Sayyah, 2012) and in legal term means the transfer of ownership of the property of the deceased, after death, to his heirs (Shahidi, 2010) The legislator who inherits his word heir, and the deceased testator, and assets of the deceased during her feet, wand calls (Emami, 2011). The wife or husband of the deceased as well, including the people who will inherit from the deceased. However, since the legislation on inheritance couples special provisions have been predicted, detailed review this issue is essential. Under the provisions of article 861 of the Civil Code inherited two things, the relative proximity and a causal relationship. The relative affinity of the natural affinity between people, resulting in the birth of another man by man is said (Shahidi, 2010) and the proximity of, it is said that there is some kind of kinship by marriage (Ibid). It explained that after the marriage, the couple will have a causal relationship. The woman and her husband with Aqrbay with Aqrbay husband to find relatives by marriage (Katouzian, 2010). Of course, these relatives may cause the inheritance among all those people are not the only couple who inherit from each other because of these relatives (Emami, 2011). It explained that after the marriage, the couple will have a causal relationship. The woman and her husband with close relatives by marriage to the husband's relatives found. (Katouzian, 2010). Of course, these relatives may cause the inheritance among all those people are not the only couple who inherit from each other because of these relatives (Emami, 2011). The important point is that couples in relation to inheritance, along with other heirs inherit the couple has always been and there never will be any of

\footnotetext{
${ }^{5}$ In permanent marriage, the husband is responsible for her Alimony. "Article 1106 of the Civil Code

${ }^{6} \mathrm{http}: / /$ www.yjc.ir/fa/news/4371084/
} 
the heirs cannot prevent them from inheriting. The husband or wife of the deceased are never prevented from inheriting other heirs of a deceased relative (Katouzian, 2010).

\subsection{Sixth Speech: Dowry}

Dowry which in Persian is said cabin, is a finance that the wife of the owner is married and the man to give it to the woman (Safai and Emami, 2013). Iran's dowry rights institution based on tradition and religion and the like cannot be found in Western law, although high dowry payments that have recently been common defects, and in particular it can be considered a barrier to his family, however, the dowry given by men to women could partially compensate for our lack of inheritance rights of women. In addition to the dowry tradition is a sign of esteem for the women's men's and women is a manifestation of the commitment of a husband for life. Sometimes a seal, which is usually when the dissolution of marriage. In the event of divorce, the woman is also sometimes financially as a dowry in his life is very effective in preventing anxiety and distress her. Dowry contrary to what some Westerners have imagined, and to our surprise, the woman selling prices because firstly, no one can sell or taxation in another. When the slave trade was abolished in the rights of man never fails, but always on the right. Second, in sales, given the price should be determined when the transaction or the contract is void. But marry dowry payments are not a condition of the validity of a contract of marriage may occur without specifying seals. In this case, the woman would be so closely to demand reasonable dowry. The dowry is a legal entity differs from the price of milk or flogged, in some places, the husband also gives her dowry to the parents or other relatives, to gain their approval for the marriage; what financial dowry from the woman and to give an interpretation, a gift that gives to the woman's husband and other relatives of the woman is not entitled to it. Milk prices or with flogged the remains of the period when parents sold her daughter by marriage and, fortunately, is less common today. In some places there's as milk price, but is actually part of the dowry that the cash is received by the girl and for her to use it to prepare her dowry so it consider that the concept of milk price and flogged in some places have changed over time and today the price of sale of girls or milk that the girl had not constitute themselves do not know the girl it yourself (Ibid). The provisions relating to dowry in 1978 and 1101 of the Civil Code state that all have been Jurisprudence. In jurisprudence and civil law dowry to the three species. A suitable dower, a proper dower and specified dower have each with terms and sentences. So here is because the financial rights of women among. To avoid prolongation word is only mentioned as a dowry.

\subsection{Seventh Speech: Solutions to Return to Sincerity during Physical Subtraction}

\subsubsection{Advice}

Women who are afraid of conflict, preach. Holy Quran in the first place, is that on getting to admonition and advice, perhaps the cause is again married life and provide comfort in the mainstream parties and the wife, for advice, we use words like beautiful and enchanting and peaceful manner adopt, with his wife to come and argue with reason and wisdom makes him happy. But sometimes conflicts over the spread within the family and with the advice the parties are not convinced it is time to turn to the second stage.

\subsubsection{Leave the Bed and Sex}

In some cases, the hatred between husband and wife, ingrained and advice, do not go. Here is the second solution leaving the common ground and lay there used to come for the parties. Leave the bed, signs of discomfort and dissatisfaction with the husband of his wife and probably cause to believe that any good way to take the fall. In addition to leave the bed, causing anger in silence and forgetting the causes of unhappiness. At this stage, the parties also need to start this deterrent at his/her home and far from the expectations of others and should not utilize their spread to other than the places bed. Users need to have the appropriate behavior to children and others, and use of these solutions should not influence their behavior with children. Not the practical life of any couple in front of guests that humiliate another. If this approach was not effective, the turn is the third stage.

\section{Conclusion}

Physical differentiation is a separation between couples, without any of the divorce, and this must be the result of a court order in the physical differences that arise from court and also in practical distinction, commitment to charity still remains. Physical differentiation in the end makes the commitment to participate in the cost of living (joint supply of living cost); nevertheless, the duty of assistance is based on a commitment to charity, remain. Commitment to charity in this case, unlike pension expenses resulting from the failure of one of the couples divorce each spouse is determined without regard to errors. But in practical discrimination, in addition to homework assistance, even the obligation to participate in the cost of living (joint supply of living cost) is also standing. According to what was said to be, commitments to expend in the two cases, the survival of alimony in iddah of a revocable divorce Iranian law analogy, because in both cases the distinction between physical and 
practical iddah revocable divorce, alimony for the survival of the marriage and the former situation is more obligatory.

But the fact that the distinction between physical and practical parity remains which is more consistent with Article 1115 of the Civil Code, which says: "If the woman's husband in a house involves fear of physical harm or financial or dignity of the woman can provide separate housing and if quotes, such loss establish, the court ruling will not return to the home of husband and as long as the woman in the home is excused maintenance will be the responsibility of the husband."

\section{Suggestions}

1) In order to protect the rights of women to seek help from legal solutions in domestic law or if the adaptation of foreign rights, should be adapted to the principles of our legal structure. Therefore, it seems, for the implementation of this support, to use the tools that have strong fundamentals in our rights.

2) Proverbs fees of woman activity at home that Article 336 of the Civil Code is the best tool to ensure women's rights and the legal entity which enjoys very strong legal basis that the vast majority of scholars have accepted it and what is needed, is a judicial mechanism to implement this legal entity.

3) Although the Iranian law in addition to criminal sanction, there are two civil remedies which include the obligation to pay and divorce. Therefore, it is suggested, third-party payment owed to public coverage would be committed, is very helpful and can be used in our rights.

\section{References}

Al-Tarihi, S. Fakhr-al-Din. (n.d.). Majma-ul-Bahrain, Vol. 3, Al-Maktab Al-Mortazaviya, Bita.

Ashtiani, M. M. (1992). Al-Nikah Book, Mashhad Print.

Bahrani, Yusuf ibn Ahmad ibn Ebrahim Mohaghegh Bahrani. (1987). Al-Hadaegh Al-Nazereh, vol. 25, Qom, Publishing subsidiary of the Islamic group teachers Qom honorable institute.

Emami, S. H. (2011). Civil Law (Vol. 1). Tehran, Islamiyah Bookstore Publications.

Hindi (Fazil), M. H. (1984). Kashf Allesam va Alebham an Ghavaed Alahkam (Vol. 2). Qom, Ayatollah Marashi library publications.

Juba'i al'Amili, Zayn al-Din, Shahid Thani. (1992). Liquefied incomprehensible to explain Islam (Vol. 1). Qom, Basirati Publications.

Katouzian, N. (2010). Foundation Lessons from the pre-emption rights, wills and inheritance. Tehran, Mizan Publication.

Makarem Shirazi, N. (1995). Nemuneh interpretation (Vol. 3). Tehran, Dar al-Kutub al-Islamiyah.

Mir Khani, Ezzat Al-Sadat. (2000). a joint assignments couple in law, women Strategic Studies, No. 8, p. 17.

Momen Sabzevari, M. B. M. (1987). Adequacy of Jurisprudence. Isfahan, Sadr Mahdavi school.

Mughniyeh, M. J. (1964). Marriage and divorce on the doctrines of the five. Beirut.

Najafi, M. H. (1987). Javaherolkalam fi Sharaye Eslam (Vol. 31.). Tehran, Al-Maktabal al-Islamiyah, printing.

Rashid Reza, M. (n.d.). Tafsir al-Manar (Vol. 4). Lebanon, Dar Al Marefa, Bita.

Roshan, M. (2014). Family Law. Tehran, Jangal.

Safai, H., \& Emami, A. (2013). Brief Family Law. Tehran, Mizan Publication.

Sayyah, A. (2012). a comprehensive dictionary of Arabic - Persian (Vol. I). Tehran, Islam Bookstore.

Shahidi, M. (2010). Inheritance. Tehran, Majd Publications.

Tabatabaei, M. H. (1984). Al-Mizan interpretation (Vol. 2). Islamic Publications Office.

Tabatabaei, S. A. (1983). kindergarten issues in a statement Jurisprudence indications (Vol. 2). Qom, Al al-Bayt Foundation.

The Holy Quran.

Tusi, Sheikh Abu Ja'far Muhammad ibn al-Hassan. (1980). Refine the verdicts (Vol. 2). study; Al-Seyed Hassan Al-Mousavi, Darassab and Dartaref.

Zuhayli, W. (1999). the Muslim family in contemporary science. Damascus, Dar Al Fekr. 


\section{Copyrights}

Copyright for this article is retained by the author(s), with first publication rights granted to the journal.

This is an open-access article distributed under the terms and conditions of the Creative Commons Attribution license (http://creativecommons.org/licenses/by/4.0/). 